\title{
The Effect of Tiwari Onion (Eleutherine americana Merr) Tablet on Blood Pressure Stability in Diagnosed Hypertension Patients
}

\author{
Widya Warastuti* \\ Department of Nursing, Poltekkes Kemenkes Palangka Raya, Palangka Raya, Indonesia
}

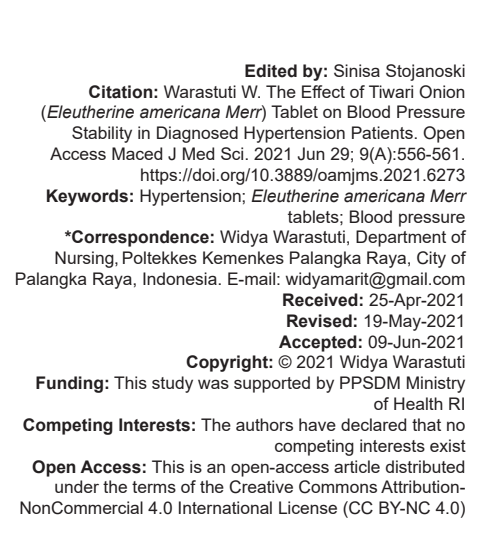

Abstract

BACKGROUND: Non-pharmacological management is carried out by adjusting the lifestyle and non-pharmacological therapy for hypertension sufferers. They use herbal therapy, which is believed to have low side effects, easy, and inexpensive, such as Eleutherine americana Merr Tea.

AIM: This study aimed to analyze Effect of E. americana Merr Tablet on blood pressure in hypertensive patients to be used as supportive therapy to reduce and stabilize blood pressure.

METHODS: This study used a quasi-experimental research design pre-post-test with a control group design, involving 30 respondents. Data collection was carried out for 1 month. Then blood pressure observations were carried out every 1 week for a month after giving $E$. americana tablets. The sampling technique was purposive sampling method. The data analysis used was the Independent Sample T-Test with a significance level of $p<0.05$.

RESULTS: The majority of respondents according to age were in the final elderly age range; 15 people (50\%) were 56-65 years old. Most of the respondents involved were female, about 18 people (60\%). The respondents hypertension category included hypertension Grade 1 (57\%) and hypertension Grade II (43\%). The independent sample t-test obtained $p=$ systole was 0.029 and diastole was $0.000(p<0.005)$. It showed a significant difference in blood pressure before and after being given $E$. americana tablets in hypertensive patients.

CONCLUSION: Significant decrease in systolic and diastolic blood pressure in patients with suspected hypertension who obtained E. americana tablets.

\section{Introduction}

There has been an increasing trend of degenerative diseases such as heart disease, stroke, diabetes mellitus, and hypertension. One of which is due to changes in people's lifestyles which are more modernized [1]. One of the degenerative diseases which are a health problem is hypertension. Hypertension is a state of abnormally high blood pressure and lasts for some time, known through several blood pressure measurements [2]. If not treated properly, people with hypertension will be at risk for various complications such as stroke, coronary heart disease, and kidney failure. Puskesmas as a primary health service has an essential role in detecting, diagnosing, and managing hypertension [3].

According to the American College of Cardiology and the American Heart Association in 2017, hypertension is classified as a systolic pressure of $130-139 \mathrm{mmHg}$ and diastolic $80-89 \mathrm{mmHg}$ on Stage 1 systolic blood pressure $\geq 140 \mathrm{mmHg}$ and diastolic $\geq 90 \mathrm{mmHg}$ at Stage 2 [3], [4]. Hypertension is one of the biggest health problems in the world, especially in developing countries. In 2008, there were more than 1 billion people or 1 in 4 adults with hypertension worldwide. This number is expected to increase to 1.6 billion by 2025 . Based on Global Burden of Disease data, $50 \%$ of heart disease is caused by hypertension. The death rate from heart disease increased to $46 \%$ in people with hypertension. Hypertension is also the most significant cause of visits to primary health-care centers, accounting for $13.1 \%$ of total visits [5].

Basic Health Research in Indonesia (2018) found that the prevalence of hypertension based on measurement results for people aged $\geq 18$ years is $34.1 \%$. Indonesia's estimated number of hypertension cases is $63,309,620$ people, while Indonesia's death rate due to hypertension is 427,218 deaths. In 2018, Palangka Raya City Health Profile data recorded the highest number of hypertension incidences in Pahandut District. An estimated number of hypertension aged $\geq 15,3077$ males and 3215 females received health services totaling 2900 people (46.9\%). Hypertension occurs in the age group of $31-44$ years (31.6\%), age $45-54$ years $(45.3 \%)$, and age $55-64$ years $(55.2 \%)$. Between the ages of 30 and 65 years, systolic pressure increases by an average of $20 \mathrm{mmHg}$ and continues to increase after age 70 . The increased risk associated with age factors largely explains isolated systolic hypertension. It is associated with increased peripheral vascular resistance in arteries [6], [7]. 
The use of pharmacologic therapy using chemical drugs often causes side effects, is expensive and is used for a lifetime for people with hypertension. Non-pharmacological management is carried out by adjusting the lifestyle and non-pharmacological therapy for hypertension sufferers. They use herbal therapy, which is believed to have low side effects, easy, and inexpensive, such as Eleutherine americana Merr Tea. [8].

Herbaceous is believed to help lower blood pressure are E. americana. This herbaceous provides many benefits for the body, including the following: Helps Reduce High Blood Pressure, a B vitamins source that can keep the body from disease attacks and eliminate toxins [9]. The potential of E. americana has been widely recognized in the community as a fruit, flavoring, and herbal plant. Many people have carried out its use since ancient times. Using this herbaceous as complementary medicine is often done for alternative medicine as a substitute for antihypertensive drugs that are relatively expensive and their use is lifelong [10]. This E. americana is a plant that can be used to the lower blood pressure [8].

The E. americana Merr contains flavonoids, saponins, and alkaloids [11]. Flavonoids are effective as diuretics, which release several fluids and electrolytes as well as toxic substances [12]. As exogenous antioxidants, flavonoids help prevent cell damage due to oxidative stress. The advantages of traditional medicine are relatively low side effects. One plant has more than one pharmacological effect and is more suitable for metabolic and degenerative diseases. E. americana Merr (Eleutherine bulbosa) is a traditional herbal medicine used by some Kalimantan people in fresh form. Besides, its tubers have antihypertensive properties [13, p. 2].

This study aimed to analyze Effect of E. americana Merr Tablet on blood pressure in hypertensive patients to be used as supportive therapy to reduce and stabilize blood pressure.

\section{Methods}

This research method was a quantitative study with the design "Quasi-Experimental Pre-Post Test with Control Group." This research was conducted in Public Health Centre's working area (Puskesmas) Kereng Bangkirai from October 2020 to November 2020. The study population were all clients who had been identified as having an increase in blood pressure above normal in Kereng Bangkirai Public Health Centre's working area.

The sample in this study was clients in the working area of Public Health Centre Kereng Bangkirai who met the criteria of 30 people divided into two groups. The sampling technique was simple random sampling using a lottery. Data collection was carried out for 1 month. Then blood pressure observations were carried out every 1 week for a month after giving E. americana tablets. The research instruments used were E. americana Merr tablet, blood pressure meters, and Note sheets.

The independent variable of this study was the E. americana Merr tablet, and the dependent variable was blood pressure stability. The data analysis technique was carried out by univariate, bivariate, and multivariate methods used were the Independent Sample t-test with a significance level of $p<0.05$

\section{Results and Discussion}

The research was conducted in the Kereng Bangkirai Public Health Center's working area in October - November 2020 by collecting primary data from respondents involved. The number of respondents taken was 30 respondents with the research results in univariate and bivariate analysis results. The univariate analysis results described respondents' distribution based on their demographic characteristics and the respondent's blood pressure (Table 1).

Table 1: Characteristics of respondents

\begin{tabular}{lll}
\hline Characteristics & $\mathrm{n}$ & $\%$ \\
\hline Ager (years) & 2 & 7 \\
$26-35$ & 4 & 13 \\
$36-45$ & 9 & 30 \\
$46-55$ & 15 & 50 \\
$56-65$ & & \\
Sex & 12 & 40 \\
Male & 18 & 60 \\
Female & 30 & 100 \\
Total & \\
\hline
\end{tabular}

Table 1 shows that most respondents according to age were in the final elderly age range, the ages of $56-65$ years as many as 15 people (50\%), and dominated by female as many as 18 people $(60 \%)$. Table 2 shows that the respondents' hypertension category included Grade 1 hypertension (57\%) and Grade II hypertension (43\%). The independent sample t-test statistical test results obtained $p=$ systole was 0.029 and diastole was $0.000(p<0.005)$. There were differences in blood pressure before and after being given the $E$. americana tablets to hypertensive patients in Kereng Bangkirai Public Health Center (Table 3).

Table 4 shows that there were two variables whose $p>0.05$. It means that statistically, there was no influence on the dependent variable. The analysis of age variables showed that Exp B: $2437 p=0.083$,

Table 2: Respondents blood pressure categories

\begin{tabular}{lll}
\hline Blood pressure categories & $\mathrm{n}$ & $\%$ \\
\hline Hypertension Grade I & 17 & 57 \\
Hypertension Grade II & 13 & 43 \\
Total & 30 & 100 \\
\hline
\end{tabular}


Table 3: Independent sample t-test results

\begin{tabular}{llllll}
\hline Variable & Measurement & Mean difference & SE & p value & $\mathrm{n}$ \\
\hline Systole & Before & -0.400 & 0.169 & 0.029 & 30 \\
& After & & & & \\
Diastole & $\begin{array}{l}\text { Before } \\
\text { After }\end{array}$ & -0.400 & 0.169 & 0.000 & \\
& & & & & \\
\hline
\end{tabular}

$p<0.05$. This result means that the increasing age would suppress E. americana to decrease blood pressure by 2.437 . On the variable gender analysis results show that $\operatorname{Exp}(B): 2.743, p: 0.060, p>0.05$. These results mean gender differences would lower the effectiveness of $E$. americana Merr in reducing blood pressure by 2743 .

Table 4: Effect of age and gender on the effectiveness of using Eleutherine americana Merr tablet

\begin{tabular}{lllllll}
\hline Independent variable & B & Wald & Sig & Exp (B) & \multicolumn{2}{c}{$95,0 \%$ C.I for EXP (B) } \\
\cline { 5 - 7 } & & & & & Lower & Upper \\
\hline Age & 0891 & 2.999 & 0.083 & 2.437 & 0.889 & 6.679 \\
Sex & 1.009 & 3.534 & 0.060 & 2.743 & 0.958 & 7.852 \\
\hline
\end{tabular}

The results showed more respondents were in the late elderly age category, aged 56-65, and 15 people $(50 \%)$. This study's results follow previous research conducted in Tarabita Village, West Likupang Sub-district, North Minahasa Regency. They show that most respondents aged $\geq 40$ years' experience hypertension [14]. Another study also revealed that the prevalence of hypertension at age $\geq 70$ years was $41.9 \%$ [15]. Another study conducted by Widjaya (2018) on the relationship between age and the Incidence of Hypertension in Kresek and Tegal Angus Subdistricts, Tangerang Regency. They found a relationship between age and the incidence of hypertension [16]. Increasing age causes physiological changes in the body, such as the thickening of the uterine wall due to a buildup of collagen in the muscle layer. Blood vessels experience narrowing and become stiff starting at the age of 45 years. Furthermore, there is an increase in peripheral resistance and sympathetic activity as well as a lack of baroreceptor sensitivity [2].

The results showed that clients with hypertension were more typical in women than $18(60 \%)$. Other studies showed that the sex of the most hypertensive patients was 58 female respondents (50.4) [16]. The prevalence of hypertension in Indonesia is more significant in women $(8.6 \%)$ than men (5.8\%). After the age of 65 years, the occurrence of hypertension in women is more pronounced than in men due to hormonal factors [17]. Other studies have also shown that after the age of 60 , hypertension is more common in women than in men [18].

The results of the independent parametric $t$ test in this study showed that the difference in the mean value of systolic blood pressure in the treatment group before being given $E$. americana Merr tablet was 3.00 and diastole 3.00. In the control group, the average difference in systolic blood pressure values before being given E. americana Merr tablet was 3.00 and diastole 3.00 , while the difference in the average value of systolic blood pressure in the treatment group after being given $E$. americana Merr tablet was 1.20 and diastole 1.13. In the control group, the average difference in systolic blood pressure after being given E. americana Merr tablet was 1.60 and diastole 1.53.

The normality test was conducted using the Kolmogorov-Smirnov test obtained a p $>0.05$. After the data were normally distributed, the statistical test used was the parametric independent sample t-test, obtained $p=0.029$ (systole) and 0.000 (diastole) at $\alpha=0.005$. The results of other studies show an effect of giving this herbaceous extract on changes in blood pressure of patients with hypertension [19]. E. americana tea is effective in lowering blood pressure in hypertensive patients [20].

The results of the research conducted by researchers obtained data from 30 respondents who studied there was a change in blood pressure in 27 people, 1 respondent experienced a decrease in blood pressure on the $3^{\text {rd }}$ day of examination and on the examination 1 week after giving day onion capsules experienced an increase in blood pressure, 1 respondent with blood pressure remains, and 1 respondent has an increase in blood pressure.

The decrease in blood pressure of respondents with hypertension was varied. A significant decrease in systolic blood pressure occurred in 1 respondent with a decrease of $30 \mathrm{mmHg}$. In comparison, a significant decrease in diastolic blood pressure occurred in 1 respondent by $30 \mathrm{mmHg}$. In contrast, the slighter decrease in systolic blood pressure occurred in 2 respondents, about $10 \mathrm{mmHg}$. The slighter decrease in diastolic blood pressure occurred in 6 respondents for about $10 \mathrm{mmHg}$. Due to the large number of compounds in the E. americana Merr tubers, such as eleuterol, eleuterin, and isoeleuterin. Those compounds are potential as antihypertensives, indicated by the improvement of coronary flow in guinea pig liver [21].

The E. americana Merr contributes to decreasing the blood pressure through its vasorelaxant effect. This herbaceous tea contains high potassium needed for electrolytes balanced and controlling the blood pressure to treat high blood pressure [20]. Furthermore, flavonoids can protect the body from free radicals through the antioxidant mechanism. This compound in the body also functions as an antioxidant. Saponins have diuretic properties by reducing plasma volume by removing water and electrolytes, especially sodium, to decrease cardiac output. Sodium and water can also influence peripheral resistance. Flavonoids are effective as diuretics, which works by removing several fluids and electrolytes and toxic substances. With a decrease in the amount of water and salt in the body, the blood vessels will loosen so that blood pressure will gradually decrease [20].

The decrease in blood pressure might increase again; the blood pressure remained and did not change. An increase in systolic and diastolic blood pressure 
in the three respondents studied. It was due to many factors influenced. The researchers could not confirm the respondents who consumed $E$. americana tablets has been given for not seeing how they consumed. Other factors are obesity and age, no history of hypertension, and a long history of hypertension among these three respondents. The treatment is given less [22]. Herbal therapy using E. americana tea can reduce blood pressure in hypertensive elderly. Besides, there was also a decrease in the systolic and diastolic mean before and after giving this tea [20].

Age and gender did not affect the effectiveness of using E. americana Merr tablets on blood pressure reduction, as indicated by linear regression results with $p>0.05$. It occurs because there was an increasing trend in hypertension prevalence according to age and generally at $\geq 40$ years of age. The arterial pressure increases with age, aortic regurgitation, and generative that are more frequent in old age. Another theory says that people with hypertension are generally people aged over 40 years. However, it does not rule out the possibility of suffering from a young age. Most prehypertension occurs at $25-45$ years; only $20 \%$ occurs under 20 years and over 50 years. The productive age rarely pays attention to health, such as eating patterns and unhealthy lifestyles such as smoking [23], [24].

Age is one of the factors that affect blood pressure. Age is related to high blood pressure (hypertension). The older a person is, the greater the risk of developing hypertension [25]. Elderly aged 55-59 years with age 60-64 years had an increased risk of hypertension by 2.18 times, age 65-69 years 2.45 times, and age $>70$ years 2.97 times. It occurs because, at that age, the large arteries lose their flexibility and become stiff. The blood at each heartbeat is forced to pass through the narrower blood vessels than usual, causing a rise in blood pressure [26], [27].

The absence of a relationship between age and systolic and diastolic blood pressure in this study occur because other factors directly affect blood pressure in the elderly, such as the food intake of the elderly. Excessive sodium consumption causes the concentration of sodium in the extracellular fluid to increase. The increase in the volume of extracellular fluid causes an increase in blood volume in the body. Thus, the heart must pump more actively to increase blood pressure [28], [29].

The absence of a relationship between sex and systolic and diastolic blood pressure in this study could occur due to other factors that affect blood pressure, such as stress levels. Lewa et al. state that the elderly who experience psychosocial stress will increase the risk of isolated systolic hypertension (HST) by 2.54 times greater than the elderly who do not experience psychosocial stress. It is statistically significant $(p=0.001)$ [30].
The previous research on E. americana tubers, empirically its pharmacological effects, can be used as antihypertensives [31]. The E. americana contains flavonoids, saponins, and alkaloids. Flavonoids are effective as diuretics, which release several fluids and electrolytes as well as toxic substances. As exogenous antioxidants, flavonoids help prevent cell damage due to oxidative stress. The advantages of traditional medicine are relatively low side effects. One plant has more than one pharmacological effect and is more suitable for metabolic and degenerative diseases [32].

Age and gender did not affect the function of the performance of the E. americana Merr tablet itself. The alkaloids in this herbal tea work like $\beta$ blockers have negative inotropic and chronotropic effects on the heart. So that cardiac output and heart rate decrease, which causes blood pressure to decrease. Saponins in E. americana tea have a diuretic effect by inhibiting the $\mathrm{Na}+/ \mathrm{K}+$ ATPase enzyme, reducing sodium, and water reabsorption, causing an increase in diuresis. The flavonoids in this tea affect the change from angiotensin I to angiotensin II, causes a vasodilating effect. It results in a decrease in total peripheral resistance, which causes blood pressure to decrease. The potassium content in this tea affects increasing diuresis. The volume of intravascular fluid decreases and causes a decrease in cardiac output. Reduced cardiac output will cause a decrease in blood pressure. Furthermore, potassium is an inhibitor of the renin-angiotensin system, which inhibits aldosterone's release, resulting in an increase in diuresis, which causes a decrease in blood volume and a decrease in blood pressure [20].

\section{Conclusion}

The E. americana Merr tablets significantly affect the systolic and diastolic blood pressure in patients with suspected hypertension. Thus, it may maintain the stability of the blood pressure of patients suspected hypertension in the working area of Public Health Centre of Kereng Bangkirai, Palangka Raya City $(p=0.000)$.

\section{Acknowledgment}

We take this opportunity to thank:

1. The Head of the PPSDM Ministry of Health RI, approved and provided the funding for implementing the Risbinakes activities

2. Director of Poltekes Kemenkes Palangkaraya, provided the opportunity and facilities to conduct research

3. The Head of the Nursing Department of the Health Polytekkes of the Ministry of Health, Palangka Raya, provided the opportunity to conduct research 
4. A team of research experts from the Poltekkes of the Ministry of Health, Palangka Raya, provided input and directions for improving the preparation of research reports and research protocols

5. Colleagues in the Nursing Department of the Health Polytechnic of the Ministry of Health, Palangka Raya, provided support and cooperation in preparing research reports

6. Various parties, for the collaboration and assistance during the research reports.

\section{References}

1. Putri LP, Sudhana IW. Gambaran prevalensi dan faktor resiko hipertensi pada penduduk usia produktif di desa rendang, kecamatan rendang, kabupaten karangasem periode oktober tahun 2013. E-J Med Udayana. 2015;4(1):1-9. https://doi. org/10.15562/ism.v3i1.64

2. Anggara $\mathrm{FH}$, Prayitno N. Faktor-faktor yang berhubungan dengan tekanan darah di Puskesmas Telaga Murni, Cikarang Barat tahun 2012. J IImiah Kesehatan. 2013;5:20-5. https://doi. org/10.25311/keskom.vol3.iss5.122

3. Paul MJ, Dredze M. Social monitoring for public health. Synth Lect Inf Concepts 2017;9(1):1-183.

4. American College of Cardiology. Guideline for the Prevention, Detection, Evaluation, and Management of High Blood Pressure in Adults. Washington, DC: American College of Cardiology; 2017.

5. Global Burden of Disease Collaborative Network. Global Burden of Disease Study 2017. Seattle, United States: Global Burden of Disease Collaborative Network; 2017. https://doi.org/10.1093/ oso/9780190662455.003.0004

6. Casey A, Benson H, O'Neill BE. The Harvard Medical School Guide to Lowering Your Blood Pressure. New York: McGrawHill; 2006.

7. Kementerian Kesehatan Republik Indonesia. Laporan Hasil Riset Kesehatan Dasar (Riskesdas) Nasional. Badan Litbangkes, Depkes RI, Jakarta: Kementerian Kesehatan Republik Indonesia; 2018. https://doi.org/10.36407/akurasi. v2i 2.177

8. Febrinda AE, Astawan M, Wresdiyati T, Yuliana ND. Kapasitas antioksidan dan inhibitor alfa glukosidase ekstrak umbi bawang dayak. [Antioxidant and alpha-glucosidase inhibitory properties of bawang dayak bulb extracts]. J Teknol Ind Pangan. 2013;24(2):161-1. https://doi.org/10.6066/ jtip.2013.24.2.161

9. Swastika A. Kitab Khasiat Buah dan Sayur Tumpas Segala Penyakit. Yogyakarta: Shira Media; 2014.

10. Ramadi A. Perbedaan Pengaruh Pemberian Seduhan Daun Alpukat (Persea Gratissima Gaerth) Terhadap Tekanan Darah Pada Pasien Hipertensi Laki-laki Yang Perokok Dengan Bukan Perokok di Wilayah Kerja Puskesmas Padang Pasir Kota Padang tahun 2012. Padang: Skripsi Universitas Andalas, 2012. https://doi.org/10.33757/jik.v1i1.32

11. Suroto HS. Bawang tiwai (Eleutherin americana Merr.) sebagai pengawet, antioksidan dan pewarna untuk pangan. J Res Technol Ind. 2016;6(12):102. https://doi.org/10.26578/jrti. v6i12.1522

12. Okhtara AN. Potential of flavonoid in mahkota dewa to reduce sistolic and diastolic blood pressure in patient with hypertension. Cardiovasc Cardiometab J. 2020;1(1):1. https:// doi.org/10.20473/ccj.v1i1.2020.26-30

13. Setyawan $A B$, Masnina R. Efektivitas teh bawang dayak untuk menurunkan kadar gula darah pasien diabetes mellitus Tipe 2.
STRADA J Ilmiah Kesehatan. 2018;7(2):7-13. https://doi. org/10.30994/sjik.v7i2.159

14. Tular GJ, Ratag BT, Kandou GD. The relationship between physical activity, family history and age with the incidence of hypertension in Tarabitan Village, West Likupang District, North Minahasa Regency. Med Kesehatan. 2017;9(3):1-6.

15. Shukuri A, Tewelde T, Shaweno T. Prevalence of old age hypertension and associated factors among older adults in rural Ethiopia. Integr Blood Press Control. 2019;12:23-31. https://doi. org/10.2147/ibpc.s212821

16. Widjaya N, Anwar F, Sabrina RL, Puspadewi RR, Wijayanti E. Hubungan usia dengan kejadian hipertensi di kecamatan kresek dan tegal angus, kabupaten tangerang. J Kedokteran YARSI. 2018;26(3):131-8. https://doi.org/10.33476/jky.v26i3.756

17. Pramana LD. Faktor-Faktor Yang Berhubungan Dengan Tingkat Hipertensi Di Wilayah Kerja Puskesmas Demak II. Undergraduate, UNIMUS; 2016. Available from: http://www. repository.unimus.ac.id/35. [Last accessed on $2021 \mathrm{Apr}$ 08] https://doi.org/10.31227/osf.io/fk2qp

18. Choi HM, Kim HC, Kang DR. Sex differences in hypertension prevalence and control: Analysis of the 2010-2014 Korea national health and nutrition examination survey. PLoS One. 2017;12(5):e0178334. https://doi.org/10.1371/journal. pone.0178334

19. Aditia A. Pengaruh Pemberian Ekstrak Bawang Dayak Terhadap Perubahan Tekanan Darah Pada Penderita Hipertensi Di Desa Tangkahen Kecamatan Banama Tingang Kabupaten Pulang Pisau Kalimantan Tengah Tahun 2017. PhD Thesis, STIKES Bethesda Yakkum Yogyakarta; 2017. https://doi.org/10.35913/ jk.v6i1.117

20. Setyawan $A B$, Burhanto $B$. Teh bawang dayak (Eleutherine americana Merr) menurunkan tekanan darah sistolik dan diastolik pada pasien hipertensi. Riset Inform Kesehatan 2019;8(2):2. https://doi.org/10.30644/rik.v8i2.234

21. Chen DL, Hu MG, Liu YY, Li RT, Yu M, Xu XD, et al. New naphthalene derivatives from the bulbs of Eleutherine americana with their protective effect on the injury of HUVECs. Molecules 2018;23:2111. https://doi.org/10.3390/molecules23092111

22. Wahyuni S, Aditia A. Pengaruh pemberian ekstrak bawang dayak terhadap perubahan tekanan darah pada penderita hipertensi di desa tangkahen kecamatan banama tingang kabupaten pulang Pisau kalimantan Tengah. J Kesehatan. 2019;6(1):1. https://doi. org/10.35913/jk.v6i1.117

23. Al-Bustan M, Majeed S, Bitar MS, Al-Asousi A. Sociodemographic features and knowledge of diabetes mellitus among diabetic patients in Kuwait. Int $Q$ Community Health Educ. 1997;17(1):65-76. https://doi.org/10.2190/ bprf-7yec-r04e-9xey

24. Saputra LG, Purwanti LE, Sari RM. Faktor risiko yang menyebabkan hipertensi pada wanita pekerja pelinting rokok di pabrik rokok berkah nalami kecamatan babadan kabupaten ponorogo. Health Sci J. 2018;2(2):2. https://doi.org/10.24269/ hsj.v2i2.156

25. Khomsan A. Pangan dan Gizi Kesehatan. Jakarta: Gramedia; 2003.

26. Rahajeng E, Tuminah S. Prevalensi hipertensi dan determinannya di Indonesia. Majalah Kedokteran Indones. 2009;59(12):580-7.

27. Sigarlaki HJ. Karakteristik dan faktor berhubungan dengan hipertensi di desa bocor, kecamatan bulus pesantren, kabupaten kebumen Jawa Tengah, Tahun 2006. Makara Kesehatan. 2006;10(2):78-88. https://doi.org/10.7454/msk.v10i2.187

28. Widyaningrum TA. Hubungan asupan natrium, kalium, magnesium dan status gizi dengan tekanan darah pada lansia di Kelurahan Makamhaji Kartasura. Skripsi. Program Studi IImu Gizi, Fakultas IImu Kesehatan, Universitas Muhammadiyah Surakarta; 2014. https://doi.org/10.21776/ 
ub.ijhn.2019.006.02.2

29. Dalimartha S. Care your Self, Hipertensi. Jakarta. Penebar PLUS+; 2000.

30. Lewa AF, Pramantara ID, Rahayujati TB. Faktor-faktor risiko hipertensi sistolik terisolasi pada lanjut usia. Berita Kedokteran Masyarakat. 2010;26(4):171-8.

31. Insanu M, Kusmardiyani S, Hartati R. Recent studies on phytochemicals and pharmacological effects of Eleutherine americana Merr. Proc Chem. 2014;13:221-8. https://doi. org/10.1016/j.proche.2014.12.032

32. Setyawan AB, Sina I, Harfiani E, Dewi NU, Supinganto A. Effect of tea concocted from bawang dayak (Eleutherine palmifolia) on cholesterol of Type 2 diabetes mellitus: Pretest-posttest control group design. Syst Rev Pharm. 2020;11(4):674-80. 